\section{Effect of a Bioactive Glass Ceramic on the Control of Enamel and Dentin Erosion Lesions}

Michelle Alexandra Chinelatti ${ }^{1}$, Camila Tirapelli ${ }^{1}$, Silmara Aparecida Milori Corona ${ }^{2}$, Renato Goulart Jasinevicius ${ }^{3}$, Oscar Peitl ${ }^{4}$, Edgar Dutra Zanotto ${ }^{4}$, Fernanda de Carvalho Panzeri Pires-de-Souza ${ }^{1}$

\author{
'Department of Dental Materials and \\ Prosthodontics, School of Dentistry of \\ Ribeirão Preto, USP - Universidade de \\ São Paulo, Ribeirão Preto, SP, Brazil \\ ${ }^{2}$ Department of Restorative Dentistry, \\ School of Dentistry of Ribeirão \\ Preto, USP - Universidade de São \\ Paulo, Ribeirão Preto, SP, Brazil \\ ${ }^{3}$ Department of Mechanical \\ Engineering, São Carlos School of \\ Engineering, USP - Universidade de \\ São Paulo, São Carlos, SP, Brazil \\ ${ }^{4}$ Department of Materials Engineering, \\ UFSCAR - Universidade Federal de \\ São Carlos, São Carlos, SP, Brazi \\ Correspondence: Michelle Alexandra \\ Chinelatti, Avenida do Café, s/n, \\ 14040-904 Ribeirão Preto, SP, \\ Brasil. Tel: +55-16-3315-4081. \\ e-mail: chinelatti@usp.br
}

Key Words: dental erosion, caries, enamel, dentin, bioglasses, biosilicate.

\section{Introduction}

The decline in tooth loss coupled with the increase in longevity and the changes in dietary habits of the general population has led to a higher prevalence and severity of non-carious lesions, such as erosion $(1,2)$. In dental erosion, the contact of tooth surfaces with non-bacterial acids results in an irreversible tissue loss due to a chemical process (3). Such pathology can be caused by intrinsic agents, such as recurrent vomiting or acid reflux, or by extrinsic agents, such as the ingestion of acidic foods, medications or drinks (4). The frequent ingestion of acidic drinks has been mentioned as a major cause of dental erosion because these substances have a $\mathrm{pH}$ of approximately 3.5 and contain citric acid and/or phosphoric acid (5). Among the treatments for controlling dental erosion, the application of fluoride has been widely discussed (2,6-8). One of the major disadvantages of this technique is the limited efficacy of fluoride in preventing mineral loss due to erosion, because the calcium fluoride layer formed during topical application is likely to be gradually dissolved by most acidic drinks $(9,10)$.

Dental caries prevention and arresting carious lesions are among the main objectives of dental health care.
Tooth structure is subject to constant demineralization and remineralization processes in the oral cavity (1). At $\mathrm{pH} \leq 5.5$, the reaction between hydrogen ions, produced by bacterial metabolism and the phosphate group of enamel crystals leads to enamel dissolution/demineralization. This process can be reversed at normal $\mathrm{pH}$ in presence of calcium and phosphorus ions. Incipient enamel lesions can be remineralized, especially using treatments to promote remineralization, as well as in the repair of natural "defects" produced by these acids in enamel fluid by the biofilm and saliva, when at neutral $\mathrm{pH}$ (remineralization) (3). The interprismatics spaces of enamel by where the acids spread also allow the entry of other ions present in the oral environment, as fluoride (3).

Hence, given the instability of fluoride in protecting dental tissues from erosion, it is important to determine methods to stabilize the dental surfaces and make them more resistant to acid challenges. In response to these comments, the optimization of the usual methods of dental caries prevention and the development of new strategies are of fundamental importance for the promotion of oral health $(12,13)$. In this context, bioactive materials such as bioglass 
have been used as remineralizing and desensitizing agents, but there are few studies describing these materials (11-13). Further research led to the development of Biosilicate, a new fully crystalline glass ceramic. To be effective, Biosilicate microparticles must be dissolved and their ions released to form hydroxycarbonate apatite crystals that obliterate the dentinal tubules more efficiently and protect the dental surface from acid attacks, inhibit demineralization and facilitate remineralization $(12,13)$.

Nonetheless, effective remineralization and the time needed for it to occur are topics that are currently under investigation. When dental erosion is still superficial, the formation of an acid-resistant surface may be a promising strategy to control the progression of such lesions.

Thus, the objective of the present study was to evaluate in vitro the effect of applying Biosilicate for controlling erosion lesions progress in enamel and root dentin, as well as to assess the effect of topical application of Biosilicate in the prevention of demineralization and in promoting remineralization of bovine enamel.

\section{Material and Methods}

- Experimental Design - Erosion

The factors evaluated in the present study included surface treatments at three levels (Biosilicate, acidulated phosphate fluoride, and no treatment) and evaluation periods at four levels $(1,7,14$ and 21 days). For each substrate (enamel and root dentin), 12 experimental groups were formed from the combination of treatments and time periods. Adopting a complete randomized block approach, the sample for each substrate consisted in 120 specimens divided randomly among the experimental groups $(n=10)$.

\section{Sample Preparation - Erosion}

Recently extracted bovine incisors were used in this study. The incisors had their crowns and roots separated at $1 \mathrm{~mm}$ below the dentin-enamel junction with a flexible diamond disc mounted in an electric precision cutter. To obtain the enamel specimens $(5 \times 5 \mathrm{~mm})$, the crowns were sectioned longitudinally in both the mesiodistal and buccolingual directions. Sections in the same directions were performed on the cervical third of the roots to obtain the root dentin specimens $(5 \times 5 \mathrm{~mm})$.

The specimens were planed and smoothed with a watercooled Politriz sanding machine; aluminum oxide sandpaper of decreasing granulations (\#600-1200 for enamel; \#10001200 for root dentin) and a $0.3 \mu \mathrm{m}$ alumina suspension in a felt disc were used. Thereafter, the specimens were washed in deionized water for $1 \mathrm{~min}$ and placed in an ultrasonic vat for $10 \mathrm{~min}$ to remove possible surface debris.

To obtain standardized specimens, the Knoop microhardness test was applied to each specimen. Five equidistant measurements $(100 \mu \mathrm{m})$ were made in the center of the specimen with a microhardness tester $(25 \mathrm{~g}$ for $5 \mathrm{~s}$ in enamel, and $10 \mathrm{~g}$ for $5 \mathrm{~s}$ in root dentin). The average of the five measurements was used as the microhardness value of the specimen; specimens with values $10 \%$ above or below this average were discarded. Based on this criterion, 120 specimens were selected for each substrate.

The selected specimens were waterproofed with three layers of acid-resistant nail polish, except for the central $3 \times 3 \mathrm{~cm}$ area of the vestibular surface, which was later used for the erosive cycle. The waterproofed surface was later considered as sound area in order to compare it to the eroded area, thus assessing the surface loss. The specimens were stored in distilled water at $37^{\circ} \mathrm{C}$ to prevent dehydration.

\section{Surface Treatment and Erosive Cycling}

The specimens were distributed randomly in 3 groups according to the surface treatment, and each group was further divided in four subgroups according to the time periods for evaluation. The specimens had a daily topical application of the respective treatment one hour before the erosive cycle, as follows:

Group 1: A 10\% Biosilicate suspension was prepared by mixing $0.1 \mathrm{~g}$ of Biosilicate in $1.0 \mathrm{~mL}$ of distilled water in 1.5 $\mathrm{mL}$ Eppendorf microtubes. This suspension was prepared immediately before application, and it was gently rubbed with a microbrush for $30 \mathrm{~s}$ on the area exposed to the erosive cycle, where it remained for 5 min (13).

Group 2: $1.23 \%$ acidulated phosphate fluoride (APF) gel was applied with a microbrush for 4 min, according to manufacturer's instructions, on the area exposed to the erosive cycle.

Group 3 (control): No surface treatment was applied to specimens.

After each application, the materials were removed carefully with absorbent paper, and the specimens remained stored in artificial saliva at $37^{\circ} \mathrm{C}$ for $1 \mathrm{~h}$.

The specimens were subjected to the following erosive cycle: daily immersion in $45 \mathrm{~mL}$ of $0.3 \%$ citric acid solution (pH 2.6) (14) for 5 min under agitation at room temperature during 21 consecutive days. After this immersion period, the specimens were maintained in artificial saliva at 37 ${ }^{\circ} \mathrm{C}$. The artificial saliva solution was changed daily before the erosive cycle.

\section{Surface Loss Measurement - Erosion}

At the end of each period $(1,7,14$ and 21 days) in the erosive cycle, the waterproof layer was removed carefully to expose the sound area that was not exposed to the acid. The surfaces were evaluated with an optical profiler (Wyko NT9100, Veeco Instruments Inc., Plainview, NY, USA). To 
determine the superficial loss $(\mu \mathrm{m})$, the unexposed areas were compared to the exposed/treated areas and digitally measured with an analysis software profiler (Wyko Vision). The software provides an output screen showing 2D plot, $X$ and $Y$ cross-sections, 3D plot, and $R$ and $S$ surface parameters.

\section{Confocal Laser Scanning Microscopy (CLSM) Analysis - Erosion}

After surface measurements at each period, the specimens of each group were fixed in acrylic slides with the vestibular surface facing upward. This surface was sectioned longitudinally through the center of the exposed area with a flexible diamond disc mounted on an electric precision cutter, providing two halves. One half of the specimen (hemispecimen) was used for confocal laser scanning microscopy. The other hemi-fragment was used for scanning electron microscopy and Rx diffraction.

For CLSM, the hemi-specimens were embedded in acrylic resin. Then, perpendicular transversal sections $(1 \mathrm{~mm})$ of specimens were obtained with a flexible diamond disc on a precision cutter and prepared using

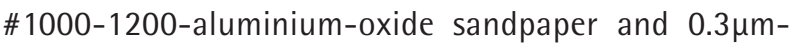
alumina suspension in a felt disc. A confocal laser scanning microscope (Leica SP5, Leica Microsystems CMS GmbH, Mannheim, D-68165, Germany) was used with an argon laser (emission wavelength of $488 \mathrm{~nm}$ ) to analyze specimens at 10x magnification. Three measurements of erosion lesion depth were performed digitally (LAS AF software, Leica Microsystems) in each specimen at 3 equidistant points $(500 \mu \mathrm{m})$ of the lesion border. Thus, an average depth was calculated for each specimen (15). For all procedures, sections were stored moist before the measurement, and re-wetting was performed regularly.

\section{Scanning Electron Microscopy (SEM) Analysis - Erosion}

Five hemi-specimens from each group were randomly selected and observed under SEM in order to verify the pattern of crystalline deposition on the surfaces derived from the treatments. First, they were prepared by immersion in a graded ethanol series of 25, 50 and 75\% for $20 \mathrm{~min}$ each, 95\% for $30 \mathrm{~min}$ and 100\% for $60 \mathrm{~min}$. The halves were fixed with their surfaces upward on metallic stubs, sputter-coated with gold and examined with a scanning electron microscope (Philips XL-30 FEG, FEl Corporate Headquarters, Hillsboro, OR, USA). Images were obtained at 1000x and 2000x magnifications for observation of the crystal deposition on the surfaces treated with the different materials.

\section{X-Ray Diffraction (XRD) Analysis - Erosion}

$X R D$ analyses were performed on disks obtained from the treated surfaces (Biosilicate and Fluoride Groups) of the remaining five hemi-specimens perpendicular to the surface sections were made with a diamond disc on a precision cutter, providing 1-mm thick disks. Disks were gently washed in deionized water for $10 \mathrm{~s}$ and placed in recipients for $1 \mathrm{~h}$ to remove moisture, in order to be maintained in silica gel until being analyzed with an x-ray diffractometer (Siemens D5005, Siemens AG, 80333 Munich, Germany). Disks were placed on glass slides inside the diffractor and were irradiated at $40 \mathrm{kV}$ and $40 \mathrm{~mA}$ for $1 \mathrm{~s}$. Spectral lines were recorded and a comparative analysis with reference data, predetermined by the diffractometer, provided the crystalline phases present on treated surfaces.

\section{Experimental Design - Caries}

The factors evaluated in the present study were topical application at three levels (Biosilicate, acidulated phosphate fluoride and no treatment - control). The sample of the study consisted in 30 fragments divided randomly among the experimental groups $(n=10)$. Quantitative response variables were surface Knoop microhardness and crosssectional Knoop microhardness. Qualitative analysis was made using images of confocal laser scanned microscopy.

\section{Sample Preparation - Caries}

Recently extracted bovine incisors were used and had their crowns and roots separated at $1 \mathrm{~mm}$ below the dentinenamel junction, with a flexible diamond disc mounted in an electric precision cutter. To obtain the $5 \times 5 \mathrm{~mm}$ enamel fragments, the crowns were sectioned longitudinally in both the mesiodistal and buccolingual directions. Sections in the same directions were performed on the cervical third of the dental roots to obtain the $5 \times 5 \mathrm{~mm}$ root dentin fragments. They were planed and smoothed with a grinding/polishing machine; aluminum oxide sandpaper of decreasing granulations (\#600-1200 for enamel; \#10001200 for root dentin) and a $0.3 \mu \mathrm{m}$ alumina suspension in a felt disc were used. After application of the alumina suspension, the fragments were washed in deionized water for $1 \mathrm{~min}$ and placed in an ultrasonic vat for $10 \mathrm{~min}$ to remove possible surface debris.

\section{Initial Surface Microhardness - Caries}

To obtain standardized fragments, the Knoop microhardness test was applied to each fragment. Five equidistant measurements $(100 \mu \mathrm{m})$ were made in the center of the fragment with a microhardness tester $(25 \mathrm{~g}$ for $5 \mathrm{~s}$ ). The average of the five measurements was used as the initial surface value of microhardness of the fragment; fragments with values 10\% above or below this average were discarded. Based on this criterion, 30 fragments were selected for each substrate. 


\section{Initial Cariogenic Challenge}

To obtain initial microscopic lesions of standardized white spot lesion, simulating patients with high caries activity, an artificial caries challenge was performed in all fragments. The specimens were repositioned with the buccal surface facing the external environment in resin blocks and fixed with wax. All surfaces, except the buccal, were covered with melted wax and stored individually in plastic containers. The initial cariogenic challenge was performed during five days. Artificial caries lesions were produced by immersion of the fragments in demineralizing solution $(\mathrm{pH}$ 4.6) for three hours and remineralizing solution $(\mathrm{pH} \mathrm{7.0)}$ for $21 \mathrm{~h}$ at $37^{\circ} \mathrm{C}$. After the artificial carious lesions formation, the specimens were kept in humidity for two days at $4{ }^{\circ} \mathrm{C}$.

\section{Topical Applications - Caries}

According Based on a complete and randomized block design, the specimens were divided according to topical application in three groups $(\mathrm{n}=10)$, as described previously in the erosive section.

\section{Cariogenic Challenge}

The samples were replaced in plastic containers and all surfaces, except for the treated surface, were covered with melted wax. The same $\mathrm{pH}$ cycling was repeated for 14 days, one per day, in order to simulate the conditions of severe cariogenic challenge. The fragments received a daily topical application 1 hour before the cariogenic challenge.

\section{Final Surface Microhardness and Cross-Sectional Microhardness - Caries}

After cariogenic challenge period, microhardness measurements were performed as described for the initial values. Surface microhardness changes $(\% \mathrm{SMH})$ was calculated as a percentage of the initial microhardness measurements, using the following equation: initial microhardness - final microhardness $\times 100$. For performing cross-sectional microhardness measurements, specimens

Table 1. Mean values and standard deviations $( \pm$ ) of enamel superficial loss $(\mu \mathrm{m})$ according to surface treatment and evaluation period

\begin{tabular}{cccc}
\hline \multirow{2}{*}{ Period } & \multicolumn{3}{c}{ Treatment } \\
\cline { 2 - 4 } & Biosilicate & APF & Control \\
\hline 1 day & $0.24( \pm 0.18) \mathrm{A}, \mathrm{a}$ & $0.47( \pm 0.12) \mathrm{B}, \mathrm{a}$ & $1.04( \pm 0.22) \mathrm{C}, \mathrm{a}$ \\
7 days & $0.27( \pm 0.20) \mathrm{A}, \mathrm{a}$ & $1.36( \pm 0.25) \mathrm{B}, \mathrm{b}$ & $1.64( \pm 0.18) \mathrm{C}, \mathrm{b}$ \\
& & $1.51( \pm 0.16)$ & $1.95( \pm 0.40) \mathrm{C}, \mathrm{c}$ \\
14 days & $0.32( \pm 0.12) \mathrm{A}, \mathrm{a}$ & $\mathrm{B}, \mathrm{b}, \mathrm{c}$ & \\
21 days & $0.43( \pm 0.21) \mathrm{A}, \mathrm{a}$ & $1.62( \pm 0.17) \mathrm{B}, \mathrm{c}$ & $2.57( \pm 0.34) \mathrm{C}, \mathrm{d}$ \\
\hline
\end{tabular}

Superscript letters, uppercase in lines and lowercase in columns, indicate significant difference $(\mathrm{p}<0.05)$ were sectioned longitudinally and fixed with melted wax and their internal side (sectional) was left exposed and polished in a polishing machine (DP-9U2; Struers S/A, Copenhagen, Denmark). After polishing, specimens were observed under an optical microscope to verify the superficial smoothness and were subjected to ultrasonic cleaning (Dabi Atlante, Ribeirão Preto, SP, Brazil) for two minutes to remove the debris. Then, indentations were made in one of the hemi sections, keeping the long axis of the diamond indenter parallel to the external surface of the enamel using a static load of $25 \mathrm{~g}$ for $5 \mathrm{~s}$. Indentations were performed under caries lesion at distances of $10 \mu \mathrm{m}, 30 \mu \mathrm{m}, 50 \mu \mathrm{m}, 70 \mu \mathrm{m}$, $90 \mu \mathrm{m}, 110 \mu \mathrm{m}$, and $200 \mu \mathrm{m}$ from the middle of the lesions. At each distance, three horizontal measurements $100-\mu \mathrm{m}$ apart were taken, and their mean was calculated.

\section{Confocal Laser Scanning Microscopy Analysis (CLSM) - Caries}

All procedures were performed as previously described for the erosive procedures.

\section{Statistical Analysis}

After verifying data normality and homogeneity, twoway ANOVA and Bonferroni's multiple comparisons test were applied at a significance level of 5\%. Data analysis was performed with a statistical software (GraphPad Prism 4.0, GraphPad Software, Inc., La Jolla, CA, USA).

\section{Results}

\section{Surface Loss Assessment - Erosion}

Surface loss values according to evaluation periods, for enamel and dentin, are shown in Tables 1 and 2, respectively.

Analyzing surface treatments, for both enamel and dentin, Biosilicate showed the lowest $(p<0.05)$ values of surface loss, regardless of the time. APF gel promoted lower $(p<0.05)$ surface loss than Control. As regard evaluation periods, Biosilicate did not show $(p<0.05)$ differences among

Table 2. Mean values and standard deviations $( \pm)$ of dentin superficial loss $(\mu \mathrm{m})$ according to surface treatment and evaluation period

\begin{tabular}{lccc}
\hline \multirow{2}{*}{ Period } & \multicolumn{3}{c}{ Treatment } \\
\cline { 2 - 4 } & Biosilicate & APF & Control \\
\hline \multirow{2}{*}{1 day } & $0.31( \pm 0.15) \mathrm{A}, \mathrm{a}$ & $1.03( \pm 0.22) \mathrm{B}, \mathrm{a}$ & $1.98( \pm 0.28) \mathrm{C}, \mathrm{a}$ \\
\hline 7 days & $0.39( \pm 0.11) \mathrm{A}, \mathrm{a}$ & $1.38( \pm 0.24) \mathrm{B}, \mathrm{b}$ & $2.22( \pm 0.17) \mathrm{C}, \mathrm{b}$ \\
14 days & $0.45( \pm 0.15) \mathrm{A}, \mathrm{a}$ & $\begin{array}{c}1.52( \pm 0.23) \\
\mathrm{B}, \mathrm{b}, \mathrm{c}\end{array}$ & $2.41( \pm 0.39) \mathrm{C}, \mathrm{c}$ \\
21 days & $0.58( \pm 0.12) \mathrm{A}, \mathrm{a}$ & $1.65( \pm 0.30) \mathrm{B}, \mathrm{c}$ & $2.73( \pm 0.32) \mathrm{C}, \mathrm{d}$ \\
\hline
\end{tabular}

Superscript letters, uppercase in lines and lowercase in columns, indicate significant difference $(\mathrm{p}<0.05)$. 
values of all periods, while APF showed differences $(p<0.05)$ among 1, 7 and 14 days of demineralization.

\section{CLSM Analysis - Erosion}

The values of erosion lesion depth according to evaluation periods, for enamel and dentin, are demonstrated in Tables 3 and 4, respectively.

As for surface treatments, for both enamel and dentin, Biosilicate showed the lowest $(p<0.05)$ lesion depth values. APF gel promoted lower $(p<0.05)$ surface loss than Control.
For evaluation periods, Biosilicate did not show ( $p>0.05)$ differences among values of all periods (Fig. 1), while APF did not show difference ( $p>0.05$ ) between 1 and 7 days. As from the seventh day, APF resulted in increasing values of lesion depths ( $p<0.05$ ) until the end of the erosive cycling (Fig. 2).

\section{SEM analysis - Erosion}

Figure 3 shows the SEM images of enamel treated with Biosilicate and APF, as well as control group, at 1 and 21 days. In the first day, Biosilicate has covered the
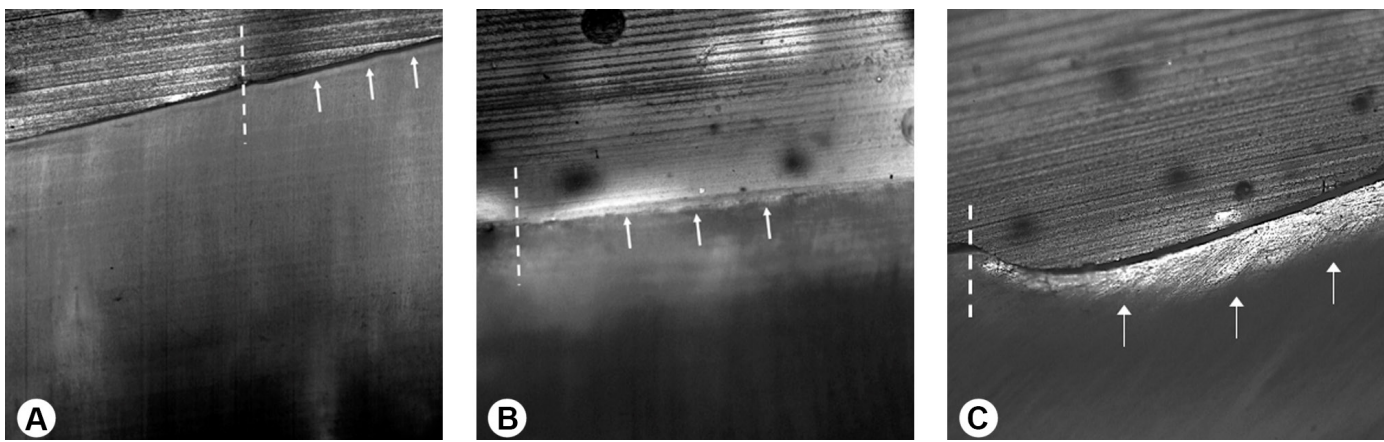

Figure 1. CLSM images of enamel erosion lesions. Treatment with Biosilicate, 1-day evaluation period (A). Treatment with Biosilicate, 21-day evaluation period (B). No treatment (Control), 21-day evaluation period (C). Dashed lines: lesion border; arrows: lesion depth.
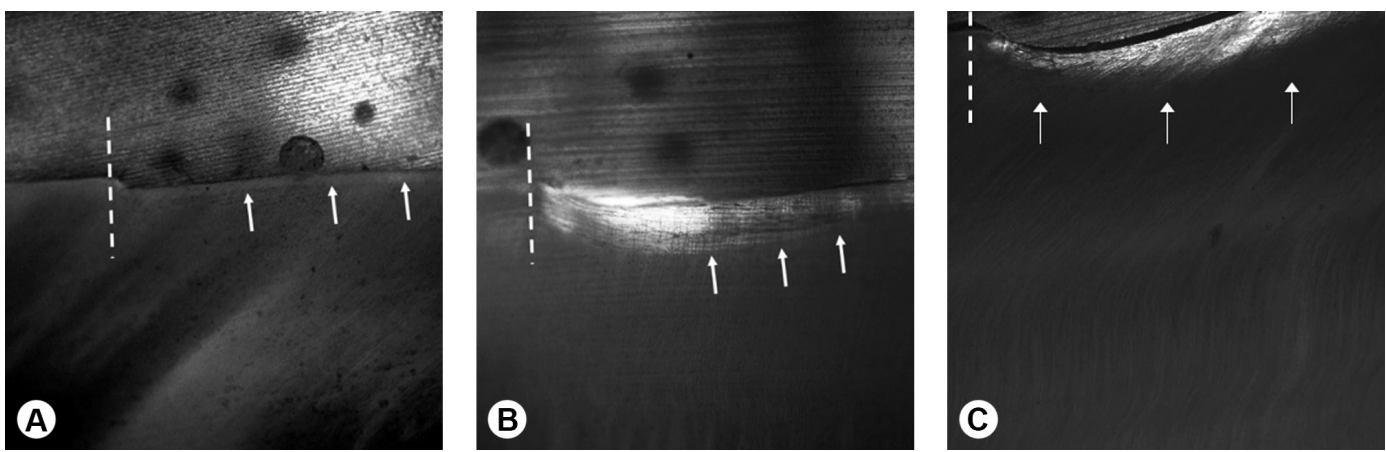

Figure 2. CLSM images of dentin erosion lesions. Treatment with Acidulated Phosphate Fluoride (APF), 1-day evaluation period (A). Treatment with Acidulated Phosphate Fluoride (APF), 21-day evaluation period (B). No treatment (Control), 21-day evaluation period (C). Dashed lines: lesion border; arrows: lesion depth.

Table 3. Mean values and standard deviations $( \pm$ ) of erosion lesion depth $(\mu \mathrm{m})$ in enamel according to surface treatment and evaluation period

\begin{tabular}{|c|c|c|c|}
\hline \multirow{2}{*}{ Period } & \multicolumn{3}{|c|}{ Treatment } \\
\hline & Biosilicate & APF & Control \\
\hline 1 day & $8.5( \pm 5.2)^{A, a}$ & $27.1( \pm 6.2)^{\text {В,a }}$ & $54.6( \pm 5.4) \mathrm{c}, \mathrm{a}$ \\
\hline 7 days & $12.3( \pm 4.6)^{\mathrm{A}, \mathrm{a}}$ & $33.9( \pm 8.1)^{\mathrm{B}, \mathrm{a}}$ & $95.5( \pm 6.9)$ c,b \\
\hline 14 days & $14.4( \pm 6.3)^{\mathrm{A}, \mathrm{a}}$ & $52.3( \pm 5.8)^{\mathrm{B}, \mathrm{b}}$ & $132.2( \pm 7.8)^{\mathrm{C}, \mathrm{c}}$ \\
\hline 21 days & $16.2( \pm 7.4) \mathrm{A}, \mathrm{a}$ & $75.3( \pm 8.3)^{\mathrm{B}, \mathrm{c}}$ & $169.1( \pm 9)^{C, d}$ \\
\hline
\end{tabular}

Superscript letters, uppercase in lines and lowercase in columns, indicate significant difference $(\mathrm{p}<0.05)$.
Table 4. Mean values and standard deviations $( \pm)$ of erosion lesion depth $(\mu \mathrm{m})$ in dentin according to surface treatment and evaluation period

\begin{tabular}{lccc}
\hline \multirow{2}{*}{ Period } & \multicolumn{3}{c}{ Treatment } \\
\cline { 2 - 4 } & Biosilicate & APF & Control \\
\hline 1 day & $18.6( \pm 8.1) \mathrm{A}, \mathrm{a}$ & $29.3( \pm 7.3) \mathrm{B}, \mathrm{a}$ & $66.7( \pm 6.5) \mathrm{C}, \mathrm{a}$ \\
\hline 7 days & $23.4( \pm 6.3) \mathrm{A}, \mathrm{a}$ & $54.1( \pm 9.2) \mathrm{B}, \mathrm{a}$ & $116.6( \pm 9.2) \mathrm{C}, \mathrm{b}$ \\
14 days & $25.5( \pm 7.4) \mathrm{A}, \mathrm{a}$ & $71.4( \pm 12.7) \mathrm{B}, \mathrm{b}$ & $183.3( \pm 9.3) \mathrm{C}, \mathrm{c}$ \\
\hline 21 days & $26.3( \pm 8.5) \mathrm{A}, \mathrm{a}$ & $84.4( \pm 10.4) \mathrm{B}, \mathrm{c}$ & $200.2( \pm 7.9) \mathrm{C}, \mathrm{d}$
\end{tabular}

Superscript letters, uppercase in lines and lowercase in columns, indicate significant difference $(\mathrm{p}<0.05)$. 
enamel surface in higher amount than APF (Fig. $3 \mathrm{~A}$ and $C$, respectively). Comparing both materials after 21 days, the permanence of the Biosilicate on enamel surface is clearly observed (Fig. 3B), different from APF, which was more easily removed (Fig. 3B).

Figure 4 shows the SEM images of dentin treated with Biosilicate and APF, as well as control group, at 1 and 21 days. In the first day, both materials had few obstructive actions (Figs. 4A and $\mathrm{C}$, respectively). After 21 days, Biosilicate was not totally removed by the acid action and remained on dentin surface (Fig. 4B); For APF treatment, it can be observed areas where the material was removed at the end of the erosive cycling (Fig. 4D).
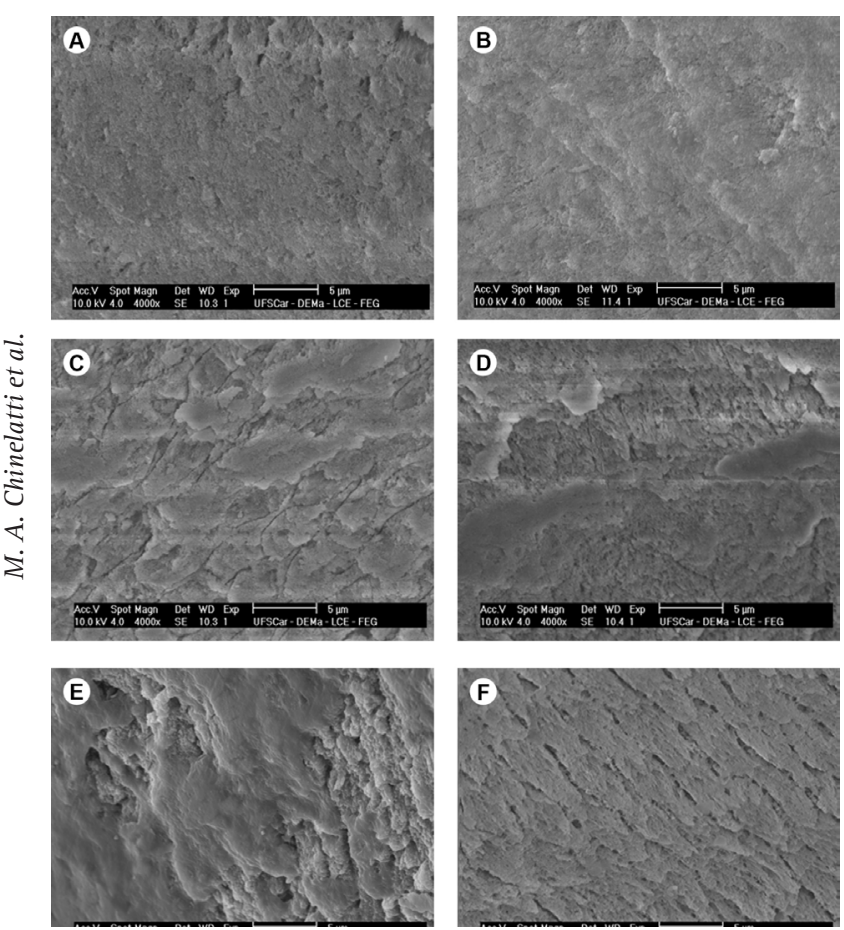

Figure 3. SEM images of enamel surfaces: Treatment with Biosilicate after 1 day (A). Treatment with Biosilicate after 21 days (B). Treatment with APF after 1 day (C). Treatment with APF after 21 days (D). No treatment (Control) after 1 day (E). No treatment (Control) after 21 days $(\mathrm{F})$.

Table 5. Mean values and standard deviations ( \pm ) of enamel surface microhardness change $(\% \Delta \mathrm{SM})$ as a function of the topical application.

\begin{tabular}{lccc}
\hline Group & $\begin{array}{c}\text { Initial } \\
\text { microhardness }\end{array}$ & $\begin{array}{c}\text { Final } \\
\text { microhardness }\end{array}$ & $\% \Delta S M$ \\
\hline Biosilicate & $334.8 \pm 4.5$ & $265 \pm 10$ & $-20.89 \pm 3.1 \mathrm{a}$ \\
APF & $335.6 \pm 5.7$ & $187.9 \pm 8.3$ & $-44.13 \pm 3.8 \mathrm{~b}$ \\
Control & $333.5 \pm 4.8$ & $56.5 \pm 10.2$ & $-83.05 \pm 4.7 \mathrm{c}$ \\
\hline
\end{tabular}

Different letters indicate statistically significant difference.

\section{$X R D$ analysis - Erosion}

Figure 5 shows the spectral results, providing the crystalline phases present in the Biosilicate-treated specimens. The analysis of XR diffraction showed that some compounds found after the treatments were common. These compounds were fluorapatite, hydroxyapatite, potassium
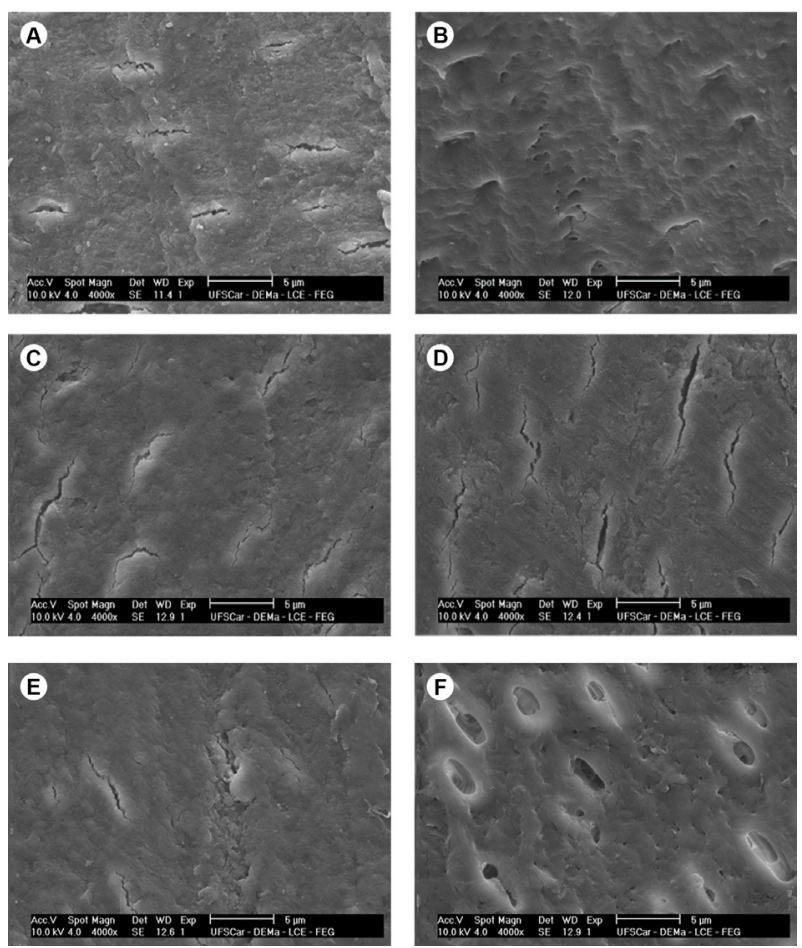

Figure 4. SEM images of dentin surfaces Treatment with Biosilicate after 1 day (A). Treatment with Biosilicate after 21 days (B). Treatment with APF after 1 day (C). Treatment with APF after 21 days (D). No treatment (Control) after 1 day (E). No treatment (Control) after21 days (F).

Table 6. Mean values and standard deviations $( \pm)$ of enamel crosssectional microhardness (KMN) as a function of the depth and topical application.

\begin{tabular}{lccc}
\hline & \multicolumn{3}{c}{ Topical application } \\
\cline { 2 - 4 } Depth & Biosilicate & APF & Control \\
& & & \\
\hline \multirow{4}{*}{$10 \mu \mathrm{m}$} & $175.2 \pm 14.7 \mathrm{~A}, \mathrm{a}$ & $93.1 \pm 12.7 \mathrm{~A}, \mathrm{~b}$ & $8.4 \pm 6.7 \mathrm{~A}, \mathrm{c}$ \\
\hline $30 \mu \mathrm{m}$ & $186.8 \pm 15.1 \mathrm{~A}, \mathrm{a}$ & $115.7 \pm 13.6 \mathrm{~A}, \mathrm{~b}$ & $16.2 \pm 6.4 \mathrm{~A}, \mathrm{c}$ \\
$50 \mu \mathrm{m}$ & $214.4 \pm 14.1 \mathrm{~B}, \mathrm{a}$ & $212.8 \pm 12.8 \mathrm{~B}, \mathrm{a}$ & $89 \pm 11.9 \mathrm{~B}, \mathrm{~b}$ \\
$70 \mu \mathrm{m}$ & $244.1 \pm 14.1 \mathrm{C}, \mathrm{a}$ & $234.8 \pm 12.6 \mathrm{~B}, \mathrm{a}$ & $159.5 \pm 10.4 \mathrm{C}, \mathrm{b}$ \\
$90 \mu \mathrm{m}$ & $252.7 \pm 15.9 \mathrm{C}, \mathrm{a}$ & $243.4 \pm 15.1 \mathrm{~B}, \mathrm{a}$ & $237.4 \pm 15.7 \mathrm{D}, \mathrm{a}$ \\
$110 \mu \mathrm{m}$ & $262.2 \pm 13.1 \mathrm{C}, \mathrm{a}$ & $253.7 \pm 12.3 \mathrm{~B}, \mathrm{a}$ & $248.2 \pm 16.5 \mathrm{D}, \mathrm{a}$ \\
$220 \mu \mathrm{m}$ & $271.2 \pm 14.1 \mathrm{C}, \mathrm{a}$ & $266.4 \pm 15.1 \mathrm{~B}, \mathrm{a}$ & $268 \pm 15.3 \mathrm{D}, \mathrm{a}$ \\
\hline
\end{tabular}

Different letters, uppercase in lines and lowercase in columns, indicate statistically significant difference. 
phosphate and calcium phosphate.

\section{Surface Microhardness Changes and Cross-Sectional Microhardness - Caries}

The application of the Biosilicate aqueous suspension resulted in significantly higher enamel surface microhardness than the APF application and control $(p<0.05)$ (Table 5).

In relation to enamel subsurface microhardness, the highest microhardness loss was observed for the control group $(p<0.05)$. The only application able to reduce the subsurface microhardness loss was the Biosilicate suspension, which differed significantly from the APF at 10- and 30- $\mu \mathrm{m}$ depths $(p<0.05)$ (Table 6).

\section{Confocal Laser Scanning Microscopy Analysis (CLSM) - Caries}

The CLMS images of caries lesion depth, according to topical application, are shown in Figure 1. Regarding topical application, Biosilicate (Fig. 6A) produced shallower lesions compared to APF (Fig. 6B) and control (Fig. 6-C) groups.

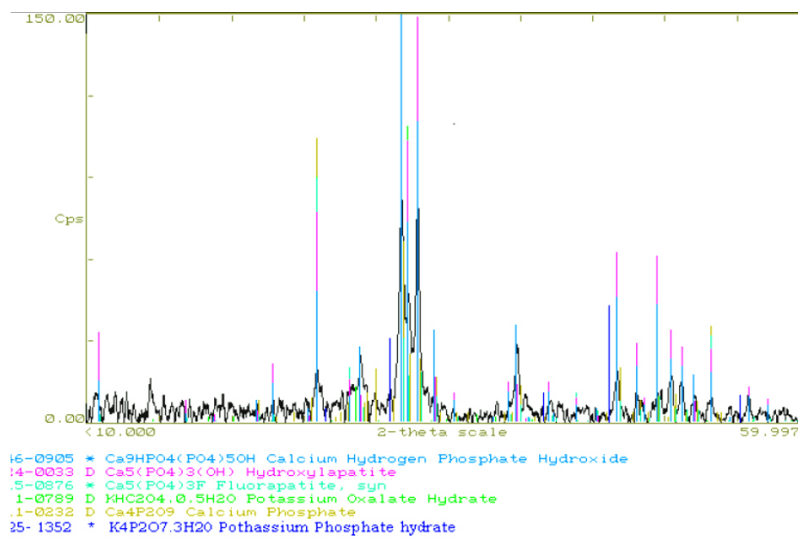

Figure 5. XRD patterns identifying the crystalline phases present in the Biosilicate-treated specimens.

\section{Discussion}

Dental erosion is characterized by initial softening of the enamel surface. This process is followed by continuous layer-by-layer dissolution of enamel crystals, leading to a permanent loss of tooth volume with a softened layer on the surface of the remaining tissue. In advanced stages, dentin becomes increasingly exposed and hypersensitivity may occur (16). Regarding therapy, causal strategies eliminating the acid impact should lead to a cessation of erosion progression and to the prevention of exposed dentin. If causal measures are not possible, special emphasis should be given to strategies enhancing the acid resistance of the dental hard tissues. A suitable measure, for example, is the application of preparations tending to form precipitates on the tooth surface (16).

In this study, an aqueous suspension containing Biosilicate microparticles applied on enamel and dentin surfaces was effective in controlling the progression of erosion and caries lesions. According to previous studies $(12,13)$ using Biosilicate as a desensitizing agent reported very fast and satisfying results regarding the obliteration of the dentinal tubules. The results showed that Biosilicate required only $24 \mathrm{~h}$ to induce the precipitation of a homogeneous hydroxycarbonateapatite layer (HCA) layer covering the entire dentin surface. Another in vitro study investigated the in situ influence of Biosilicate on whitened enamel and dentin surfaces using the Knoop hardness test. The results indicated that the biomaterial benefited the tooth hardness and morphology, preventing demineralization (11).

Biosilicate is the designation of the particular composition $23.75 \mathrm{Na}_{2} \mathrm{O}-23.75 \mathrm{CaO}-48.5 \mathrm{SiO}_{2}-4 \mathrm{P}_{2} \mathrm{O}_{5}$ (wt.\%). Under controlled double stage heat treatments, this material can be engineered to compose one (1P) or two crystalline phases (2P): a sodium-calcium silicate $\left(\mathrm{Na}_{2} \mathrm{CaSi}_{2} \mathrm{O}_{6}\right)$ or both $\mathrm{Na}_{2} \mathrm{CaSi}_{2} \mathrm{O}_{6}$ and a sodium-calcium phosphate $\left(\mathrm{NaCaPO}_{4}\right)$ phase. When bioactive silicate glasses
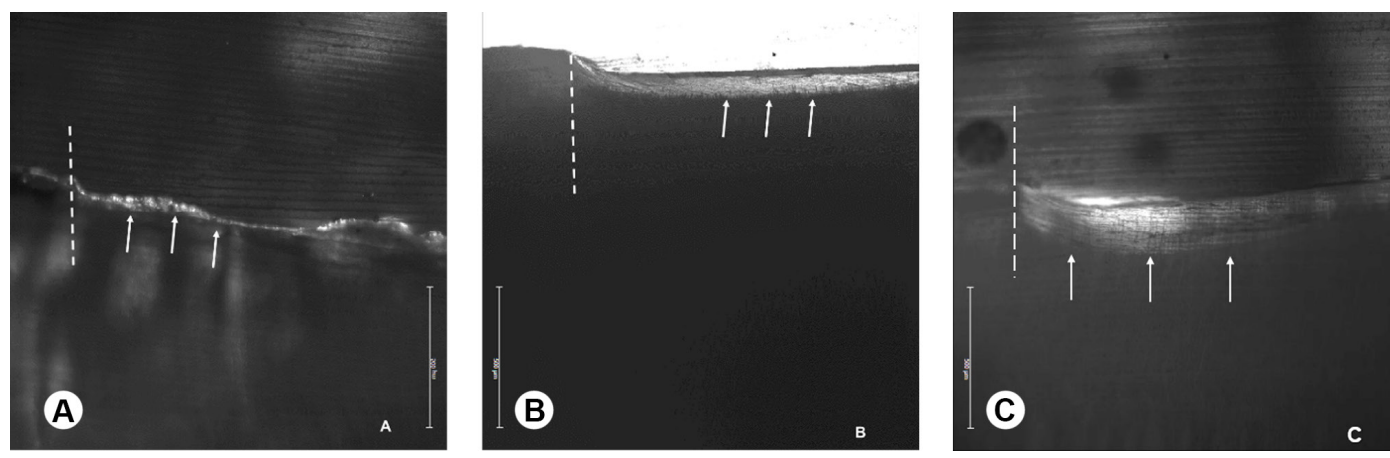

Figure 6. CLSM images of enamel caries lesions. Application of Biosilicate (A) and APF (B). No application- control- (C). Dashed line: lesion border. Arrows: lesion depth. 
are in contact with body fluids, they undergo five-stage reactions, which lead to the formation of HCA on its surface (17). Initially, alkaline ions are leached and replaced in the glass structure by $\mathrm{H}^{+}$or $\mathrm{H}_{3} \mathrm{O}^{+}$cations from the fluid (stage I). This causes an increase in the local $\mathrm{pH}$ causing the rupture of $\mathrm{Si}-\mathrm{O}-\mathrm{Si}$ bonds and silicon is released into the fluid in the form of silanols $\left[\mathrm{Si}(\mathrm{OH})_{4}\right]$ (stage II). If the local $\mathrm{pH}$ is lower than 9.5 , the silanol groups polymerize on the glass surface, forming a silica gel layer (stage III) (18).

The open structure of silica gel allows the continuity of ionic exchange between the glass and the fluid. Calcium and phosphate ions diffuse from the glass and with the calcium and phosphate ions from the fluid, form an amorphous calcium phosphate layer over the silica gel (stage IV). After the thickness increase due to both the silica gel and the amorphous calcium phosphate layer, the incorporated carbonate species in the latter begins to crystallize into HCA. The HCA is chemically and structurally similar to the mineral apatite phase found in mineralized tissues (18). The formation of a HCA layer at the material/tissue interface is accepted as a necessary condition for the formation of a chemical bond between the material and tissue (17).

APF has been used to prevent caries in order to interfere in the balance of demineralization. Fluoride is able to incorporate on dental substrate, preventing the development of carious lesions, inhibiting enamel demineralization, and enhancing remineralization through mineral gains (19). In this study, compared to Biosilicate, the use of fluoride resulted in no significant effect on enamel and dentin erosion. Fluoride interacts with the dental hard tissues by replacing the hydroxyl ions from the hydroxyapatite through an ion exchange mechanism, resulting in less soluble mineral forms, such as fluorapatite or fluorhydroxyapatite (19). Fluoride ions can also form non-stoichiometric $\mathrm{CaF}_{2}$-like deposits, which could serve as an additional layer during the erosive attack or serve as a fluoride reservoir for remineralization. The formation of the $\mathrm{CaF}_{2}$ layer is believed to be the main mechanism involved in the fluoride protection against dental erosion. However, in erosion, the fluoride present on enamel and dentin surfaces is likely to be readily dissolved due to the lower $\mathrm{pH}$ of the acids (19), thereby offering limited protection, which could explain the results shown by fluoride groups.

In the literature, many techniques have been used to investigate the effects of erosive attacks on dental hard tissues. Surface profilometry, microradiography, chemical analysis, micro-indentation and SEM were considered the most established laboratory assessment in evaluating enamel erosion (20). In the present study, optical profilometry, confocal laser scanning microscopy (CLSM), scanning electron microscopy (SEM) and X-ray diffraction were selected to analyze the effect of Biosilicate and fluoride on enamel and dentin erosion in order to measure tooth loss accurately and provide visual information on surface precipitates and change of the surface morphology.

According to Rodriguez and Bartlett (21), 3D optical measurements are a better choice to examine the substrate alteration, which provide a more accurate assessment than other techniques. Some of the differences between the results obtained using different surface methodologies, especially those between contact and non-contact methods, may be explained by noting that the results of optical measurements are influenced not only by purely geometrical changes in the surface (22), but also by chemical changes induced by processing that might influence the local index of refraction of the surface.

The exposed organic matrix of eroded dentine is prone to desiccation and shrinkage. Since most non-contact devices do not allow measurements in water, it is recommended to keep the specimens wet until measurements are performed to avoid any dimensional change (23). In dentine, moisture control is essential, because dentine, especially when demineralized, is prone to shrinkage, which interferes with several measuring methods or creates artifacts (24).

The use of CLSM to quantitatively assess erosive enamel and dentin loss has so far not been investigated. This study showed high precision of this method and found that CLSM predicts different degrees of substance loss with high accuracy. Furthermore, CLSM allows sub-surface analyses and a comprehensive assessment of the erosive tooth lesions, and might be suitable for sequential quantitative measuring of natural surfaces as well. In conclusion, CLSM seems promising to non- or semi-destructively assess erosive losses.

Erosion, abrasion and attrition rarely act alone but interact with each other and abrasion of erosively altered dental hard tissues is considered as the most important interaction (25). The challenge of both laboratory and in situ studies is to strike a balance between the intention to simulate clinical conditions and the need to conduct experiments in a rational and practicable way as well as in a short time to obtain measurable results. This conversely emphasizes the need for further development in this field.

Based on the obtained results and within the limitations of an in vitro study, it may be suggested that Biosilicate provides superior and continuous remineralizing effect for control of erosion and caries lesions during the studied period.

\section{Resumo}

Este estudo avaliou o efeito de uma vitrocerâmica bioativa para o controle de lesões de erosão e cárie. Fragmentos $(n=10)$ de esmalte bovino e dentina radicular receberam aplicação diária de diferentes tratamentos (Biosilicato; Fluoreto de Fosfato Acidulado - APF; não tratado - controle) durante a realização de ciclos erosivos. As superfícies foram analisadas com profilometria óptica 3D para quantificar a perda superficial em quatro 
períodos (1, 7, 14 e 21 dias), bem como a profundidade da lesão com microscopia confocal de varredura a laser. Para a avaliação da progressão de cárie, foi obtida a microdureza Knoop inicial de fragmentos de esmalte bovino. As lesões cariosas iniciais foram desenvolvidas e os espécimes foram divididos em três grupos $(n=10)$, de acordo com a aplicação tópica diária (Biosilicato; APF; sem aplicação - controle) durante os ciclos de desmineralização por 14 dias. A microdureza final foi obtida para calcular a perda da microdureza superficial. A desmineralização sub-superficial foi analisada utilizando microdureza transversal (profundidades 10, 30, 50, 70, 90, 110 e $220 \mu \mathrm{m}$ ). Os dados foram testados utilizando ANOVA e teste de Tukey $(\alpha=5 \%)$. Os resultados da avaliação erosiva mostraram que o Biosilicato promoveu os menores valores $(p<0,05)$ de perda superficial, independente do tempo, tanto para o esmalte como para a dentina; APF promoveu menor $(p<0,05)$ perda de superficie do que controle; analisando os períodos de tempo, APF não mostrou diferença $(p>0,05)$ entre 14 e 21 dias de desmineralização. Os resultados da avaliação da cárie no esmalte mostraram que o Biosilicato resultou em maiores $(p<0,05)$ valores de microdureza superficial e subsuperficial do que as aplicações APF e controle. Pode-se concluir que a aplicação de Biosilicato apresentou maior potencial de redução da perda superficial e desenvolvimento de lesões de erosão e cárie.

\section{Acknowledgements}

This study was funded by FAPESP - São Paulo State Research Foundation.

\section{References}

1. Zero DT, Lussi A. Erosion - chemical and biological factors of importance to the dental practitioner. Int Dent J 2005;55:285-290. doi: 10.1111/j.1875-595X.2005.tb00066.x

2. Lussi A. Dental erosion - novel remineralizing agents in prevention or repair. Adv Dent Res 2009;21:13-16.

3. Imfeld T. Dental erosion. Definition, classification and links. Eur J Oral Sci 1996;104:151-155.

4. Lussi A, Jaeggi T, Zero D. The role of diet in the aetiology of dental erosion. Caries Res 2004;38:34-44.

5. Lussi A, Jaeggi T. Erosion - diagnosis and risk factors. Clin Oral Investig 2008;12:S5-S13.

6. Hove $L H$, Holme $B$, Young $A$, Tveit AB. The erosion-inhibiting effect of TiF4, SnF2, and NaF solutions on pellicle-covered enamel in vitro. Acta Odontol Scand 2007;65:259-264.

7. Schlueter N, Ganss C, Mueller U, Klimek J. Effect of titanium tetrafluoride and sodium fluoride on erosion progression in enamel and dentine in vitro. Caries Res 2007;41:141-145.

8. Ganss C, Schlueter N, Hardt M, Schattenberg P, Klimek J. Effect of fluoride compounds on enamel erosion in vitro: A comparison of Amine, sodium and stannous fluoride. Caries Res 2008;42:2-7.

9. Larsen MJ: Prevention by means of fluoride of enamel erosion as caused by soft drinks and orange juice. Caries Res 2001;35:229-234.

10. Larsen MJ, Richards A. Fluoride is unable to reduce dental erosion from soft drinks. Caries Res 2002;36:75-80.

11. Pinheiro HB, Lopes B, Klautau EB, Cardoso J, Silva BR, Cardoso PEC. Influence of bioactive materials used on the dentin surface whitened with carbamide peroxide 16\%. Materials Res 2010;13:273-278.

12. Tirapelli C, Panzeri H, Soares RG, Peitl O, Zanotto ED. A novel bioactive glass-ceramic for treating dentin hypersensitivity. Braz Oral Res 2010;24:381-387.

13. Tirapelli C, Panzeri H, Lara EH, Soares RG, Peitl O, Zanotto ED. The effect of a novel crystallized bioactive glass-ceramic powder on dentine hypersensitivity: a long-term clinical study. J Oral Rehabil 2011;38:253262. doi: 10.1111/j.1365-2842.2010.02157.x

14. Shellis RP, Barbour ME, Jones SB, Addy M. Effects of $\mathrm{pH}$ and acid concentration on erosive dissolution of enamel, dentine, and compressed hydroxyapatite. Eur J Oral Sci 2010;118:475-482.

15. Carvalho FG, Fucio SB, Sinhoreti MA, Correr-Sobrinho L, PuppinRontani RM. Confocal laser scanning microscopic analysis of the depth of dentin caries-like lesions in primary and permanent teeth. Braz Dent J 2008;19:139-144.

16. Lussi A, Schlueter N, Rakhmatullina E, Ganss C. Dental erosion - an overview with emphasis on chemical and histopathological aspects. Caries Res 2011;45:2-12.

17 Hench LL. The story of Bioglass. J Mater Sci: Mater Med 2006;17:967978.

18. Crovace MC, Souza MT, Chinaglia CR, Peitl O, Zanotto ED. Biosilicate ${ }^{\circledR}$ - A multipurpose, highly bioactive glass-ceramic. In vitro, in vivo and clinical trials. J Non-Cryst Solids 2016;432:90-110.

19. Lippert F, Hara AT, Martinez-Mier EA, Zero DT. In vitro caries lesion rehardening and enamel fluoride uptake from fluoride varnishes as a function of application mode. Am J Dent 2013;26:81-85.

20. Barbour ME, Rees JS. The laboratory assessment of enamel erosion: a review. J Dent 2004;32:591-602.

21. Rodriguez JM, Bartlett DW. A comparison of two-dimensional and three-dimensional measurements of wear in a laboratory investigation. Dent Mater 2010;6:e221-e225.

22. Heurich $E$, Beyer $M$, Jandt $K D$, Reichert J, Herold V, Schnabelrauch $M$, et al.. Quantification of dental erosion--a comparison of stylus profilometry and confocal laser scanning microscopy (CLSM). Dent Mater 2010;26:326-336.

23. Attin $\mathrm{T}$, Becker $\mathrm{K}$, Roos $\mathrm{M}$, Attin $\mathrm{R}$, Paqué $\mathrm{F}$. Impact of storage conditions on profilometry of eroded dental hard tissue. Clin Oral Investig 2009;13:473-478.

24. Ganss $C$, Lussi A, Scharmann I, Weigelt T, Hardt M, Klimek J, et al.. Comparison of calcium analysis, longitudinal microradiography and profilometry for the quantitative assessment of erosion in dentine. Caries Res 2009;43:422-429.

25. Shellis RP, Addy $M$. The interactions between attrition, abrasion and erosion in tooth wear. Monog Oral Sci 2014;25:32-45.

Received February 6, 2017 Accepted April 6, 2017 